\title{
Corporate Governance Mechanisms and Auditor Choice: Evidence from China
}

\author{
Noel W. Leung ${ }^{1} \&$ Mei-Ai Cheng ${ }^{2}$ \\ ${ }^{1}$ Finance Department, Reyoung Pharmaceutical Holdings Limited, Hong Kong \\ ${ }^{2}$ Department of Accounting Information, National Taipei University of Business, Taiwan \\ Correspondence: Noel W. Leung, 23/F., On Hong Commercial Building, 145 Hennessy Road, Wanchai, Hong \\ Kong. Tel: 852-2925-2388. E-mail: noelleung@pchome.com.tw
}

Received: July 2, 2014

doi:10.5539/ijbm.v9n9p41
Accepted: July 24, 2014

Online Published: August 22, 2014

URL: http://dx.doi.org/10.5539/ijbm.v9n9p41

\begin{abstract}
This paper provides empirical evidence on the association between corporate governance mechanisms and the choice of high-quality and low-quality auditors (hereafter "auditor choice") based on firm's data from Chinese listed firms between 2007 and 2012. Consistent with most literature, this paper adopts Big 4 auditors as the proxy for high-audit quality. Our findings indicate that certain corporate governance factors, ownership of the largest shareholders, the aggregate of ownership of other large shareholders, percentage of independent directors in the board, dual-list status and marketization, have significant positive influence on auditor choice. More specifically, ownership of the largest shareholders exhibits a U-shape relationship for the auditor choice: in the lower ownership, a Chinese listed firm would prefer a low-quality auditor, while up to the threshold level of ownership, a Chinese listed firm would prefer a high-quality auditor. This paper also explains several possible reasons why Big 4 auditors are still uncommon in Chinese stock market.
\end{abstract}

Keywords: corporate governance mechanisms, auditor choice, Big 4 auditors

\section{Introduction}

\subsection{Historical Background of Accounting (Auditing) Profession in China}

External (or independent) audit (hereafter "audit") is regarded as one of the effective monitoring mechanisms in the global capital markets because in attesting the creditability of accounting information provided by management (the agent), an auditor (another agent) plays an external monitoring role on behalf of the shareholders (the principal) and an audit is an essential component of the corporate governance mechanisms (e.g., Ashbaugh \& Warfield, 2003; Fan \& Wong, 2005).

After the establishment of the People's Republic of China (hereafter "China") in 1949, the accounting (or auditing) profession in China became non-existent because all enterprises were owned by the state and run by the civil servants. After the open door policy in 1980s, auditing profession has been developed as demands emerged for verification of capital contributions and audits of annual financial statements and tax returns of the Sino-foreign enterprises by non-government employed professionals. The establishment of Shanghai Stock Exchange and Shenzhen Stock Exchange in 1990s facilitated the development of new accounting and auditing standards and accounting profession in China because the annual financial statements of any Chinese listed firm have to be audited by Chinese certified public accountants (Chinese CPAs). The governance of both public and private enterprises by independent auditors has gradually been employed by the government as an important mechanism in transformation of Chinese economy (Lin \& Liu, 2009).

Most Chinese accounting firms were initially established or sponsored by government agencies or social institutions (Lin \& Liu, 2009). Under such historical reason, the independence and audit quality services were challenged by various user groups, and especially, some scholars find that the audit opinion of financial statements of some local state-owned enterprises (SOEs) and those private firms with political connections and the auditors rarely issued modified audit opinion even though they had found some irregularities (e.g., Lin \& Liu, 2009). Liu, Wang and $\mathrm{Wu}$ (2011) further find that two types of guanxi, "firm-level connections derived from state ownership and personal connections developed through management with external auditors", have a close association with auditors' independence in China. 
Currently, the accounting profession in China is governed by the Chinese Institute of Certified Public Accountants, and only those accounting firms with "The Securities and Futures Related Business License" are eligible to conduct external audits of Chinese listed firms (Note 1). Institutional framework concerning the accounting profession has been well established in line with the international trend, and both civil and criminal responsibilities related to the frauds by the auditors have been established (see Appendix 1). Most audit frauds related to Chinese listed firms are investigated and punished by the China Securities Regulatory Committee (CSRC) (Note 2) (see two examples in Appendix 2). Therefore, the quality and independence of Chinese auditors have been substantially improved and such governance mechanism helps establish a more effective functioning of auditing services in China. Nonetheless, due to the historical, political and economic factors, auditing services in China are dominated by domestic accounting firms for the provision of external audit services to Chinese listed firms, and those accounting firms with international alliance (e.g., Big 4 and international second-tier firms) are still uncommon in Chinese stock market.

\subsection{Motivation of the Study}

There has been a lot of literature concerning the association of corporate governance mechanisms and audit choice in Chinese stock market mostly based on the firm's data prior to 2006 and those studies suggest that Big 4 auditors (Note 3) are the proxy for high-quality, because they are less politically influenced and have greater resources for the provision of auditing services (e.g., Boone, Khurana \& Raman, 2010; Lin \& Liu, 2009; Li \& Luo, 2011).

Since 2006, there has been a substantial reform of institutional framework in China, including: (1) the adoption of International Financial Reporting Standards and International Statements on Auditing into respective standards in China with effect from 2007; (2) the implement of share reform under which ownership of the largest shareholder in a particular Chinese listed firm has been converted from non-tradable shares to tradable ones, and therefore, the largest shareholder can realize its shares for cash, rather than expropriating the listed firm; and (3) CSRC has allowed the foreign institutional investors (e.g., Morgan Stanley, Goldman Sachs) to participate directly in Chinese stock market under Qualified Foreign Institutional Investors (QFII), and therefore, those institutional investors would demand higher standard in corporate governance and enhance the effectiveness of audit monitoring in China. Further, there is a significant expansion of Chinese stock market between 2006 and 2012, in terms of the number of Chinese listed firms and the amount of raised capital, especially that from foreign investors, while the non-tradable ownership in Chinese listed firms have been reduced under the share reform (see Table 1). The change in ownership structure of Chinese listed firms may also lead the change of other corporate governance mechanisms. Accordingly, it is interesting to re-examine the effect of corporate governance mechanisms on the choice of high-quality and low-quality auditors (hereafter "auditor choice") in Chinese stock market.

Table 1. Development of Chinese stock capital from 2001 to 2012

\begin{tabular}{|c|c|c|c|c|c|c|c|}
\hline Year & $\begin{array}{l}\text { No. of } \\
\text { listed } \\
\text { firms }\end{array}$ & $\begin{array}{l}\text { Total raised } \\
\text { capital } \\
\text { RMB' } \\
\text { Billion }^{1} \\
\end{array}$ & $\begin{array}{l}\text { Raised capital from } \\
\text { foreign investors }(\mathrm{H}, \mathrm{N} \\
\text { shares }) \\
\text { RMB' Billion }^{2}\end{array}$ & $\begin{array}{l}\text { Total issued capital } \\
\text { (Billion shares) }^{3}\end{array}$ & $\begin{array}{l}\text { Tradable } \\
\text { shares } \\
\text { (Billion } \\
\text { shares) }^{3}\end{array}$ & $\begin{array}{l}\text { Tradable } \\
\text { portion } \\
(\%)\end{array}$ & $\begin{array}{l}\text { Non-tradable } \\
\text { portion (\%) }\end{array}$ \\
\hline 2001 & 1160 & 125.2 & 7.0 & 483.8 & 148.1 & 30.6 & 69.4 \\
\hline 2002 & 1224 & 96.2 & 18.2 & 546.3 & 168.0 & 30.8 & 69.2 \\
\hline 2003 & 1287 & 135.8 & 53.4 & 599.8 & 189.7 & 31.6 & 68.4 \\
\hline 2004 & 1377 & 151.1 & 64.8 & 671.5 & 219.4 & 32.6 & 67.3 \\
\hline 2005 & 1381 & 188.3 & 154.4 & 716.4 & 249.9 & 34.9 & 65.1 \\
\hline 2006 & 1434 & 559.4 & 313.1 & 1268.4 & 344.5 & 27.2 & 72.8 \\
\hline 2007 & 1550 & 868.0 & 95.7 & 1700.0 & 493.4 & 29.0 & 71.0 \\
\hline 2008 & 1625 & 385.2 & 31.7 & 1890.0 & 696.5 & 36.9 & 63.1 \\
\hline 2009 & 1718 & 612.5 & 107.3 & 2060.6 & 1420.0 & 68.9 & 31.1 \\
\hline 2010 & 2063 & 1197.2 & 236.6 & 2698.4 & 1944.2 & 72.1 & 27.9 \\
\hline 2011 & 2342 & 581.5 & 74.1 & 2974.5 & 2250.0 & 75.6 & 24.4 \\
\hline 2012 & 2494 & 413.4 & 100.7 & 3183.4 & 2477.8 & 77.8 & 22.2 \\
\hline
\end{tabular}

Sources: ${ }^{1}$ Table 19-13 Number of Listed Companies, China Statistical Yearbook - 2013 and ${ }^{2}$ Table 19-14 Issued Share and Raised Capital, China Statistical Yearbook $-2013,{ }^{3}$ Table 19-15 Trading Summary for Stocks, China Statistical Yearbook - 2013 and Table 20-17 Trading Summary for Stocks, China Statistical Yearbook - 2007). 
This study focuses on the firm's data from 2007 to 2012, reflecting the substantial reform of institutional framework and the change of Chinese accounting and auditing practices after 2007. The paper is organized as follows: Section 2 reviews relevant prior studies in the literature, Section 3 describes variable and regression model of this study, Section 4 presents the empirical results and interpretation and Section 5 concludes the results of the study.

\section{Literature Review}

The separation of ownership (the principal) and management (the agent) can result in opportunistic management behaviours and serve agency problems in firms (Fama \& Jensen, 1983) and agency costs are likely to increase due to asymmetric information between managers and dispersed equity stakeholders (Jensen \& Meckling, 1976). However, concentrated ownership of Chinese listed firms is common and therefore, the single largest (controlling) shareholders generally serve to monitor management and the demand for audit as a monitoring mechanism may be limited. Because of the protection of minority interest, there are great demands for audits to serve as a monitoring (governance) mechanism, depending on the levels of audit quality (Lin \& Liu, 2009).

\subsection{Big 4 Auditors as High Audit-Quality}

Audit quality means "technical aspect - the ability to detect misstatements" and "independent aspect - willing to report the misstatements uncovered in the audit work" (Lee, Stokes, Taylor \& Walter, 2003).

Most foreign scholars adopt Big 4 auditors as the proxy for high audit-quality. DeFond, Wong and Li (2000) find that big auditors are more likely to issue the qualified audit opinion in China. Francis (2004) also claims that audits of Big 4 auditors are of higher audit-quality than non-Big 4 auditors because Big 4 auditors can charge higher audit fee for higher audit quality through more audit effort and greater expertise of the auditor. Nevertheless, Boone, Khurana and Raman (2010) find little difference in actual audit quality but a more pronounced difference in perceived audit quality between Big 4 and second-tier firms from 2003 to 2006 in U.S.

However, Chinese auditing market presents an interesting issue for the study of auditor choice because Chinese accounting profession is not only regulated, but also administrated, by government agencies (e.g., Ministry of Finance, CSRC, etc.) (Lin \& Liu, 2009). Some Chinese scholars adopt "Top 10" firms (including Big 4 auditors) as high-quality auditors in China (e.g. Lin \& Liu, 2009; Li \& Luo, 2011). Even though Big 4 auditors are rare in Chinese stock market, several scholars still adopted Big 4 and non-Big 4 auditors to proxy for high-quality and low-quality, respectively, mainly because Big 4 auditors should possess a higher degree of industrial expertise and are less politically influenced by local governments in China (e.g., Chen, Shrome \& Su, 2001; Simunic \& Wu, 2009; Chen, Su \& Wu, 2009; Guedhami, Pittman \& Saffar, 2009; Wang \& Xin, 2011).

This study also adopts Big 4 auditors as the proxy for high-quality auditors.

\subsection{Corporate Governance and Auditor Choice}

There is a general perception that listed firms have to take a trade-off in their auditor choice decisions, (1) to hire high-quality auditors to signal effective audit monitoring and good corporate governance to lower their capital raising costs, and (2) to select low-quality auditors with less effective audit monitoring in order to recap private benefits derived from weak corporate governance and less-transparent disclosure (the opaqueness gains) (Lin \& Liu, 2009).

Ownership structure. There are two controversial issues on the concentrated ownership on the auditor choice. On one hand, some scholars argue that with high ownership concentration, the firms' financial reporting is likely to be opaque due to the incentives for the controlling shareholders' rent-seeking and expropriation (Copley \& Douthett, 2002), and because large shareholder would try to maximize their private benefits through tunneling or expropriation of other shareholders (LaPorta, Lopez-De-Silanes Shleifer \& Vishny, 2002; Anderson, Kadous \& Koonce, 2004). Lin and Liu (2009) further find Chinese listed firms with larger controlling shareholders are less likely to hire high-quality auditors from 2001 to 2004. On the other hand, a controlling shareholder may also introduce effective monitoring mechanisms that restrict his/her abilities to expropriate Chinese listed firms and therefore mitigate the agency conflict (Ang, Cole \& Lin, 2000) and firm with such agency problems are more likely to hire Big 4 (previously Big 5) auditors (Fan \& Wong, 2005). Further, after share reform, most controlling shareholders of Chinese listed firms can convert their ownership from non-tradable shares to tradable ones, so they can realize their shares of Chinese listed firms for cash. Accordingly those listed firms may have an incentive to hire high-quality auditors for the protection of their interests as well as that of other shareholders. Other large shareholders may demand high-quality auditors. Leung and Cheng (2013) find that the higher the degree of ownership concentration among other large shareholders, the higher the firm value because the 
alignment of those large shareholders can challenge the acts of the largest (controlling) shareholders. Therefore, other largest shareholders are assumed to prefer high-quality auditors for the protection of their interests.

Internal management structure. Agency theory assumes that the directors and top executives, as agents, do not prefer an effective monitoring mechanism to them and an opaque financial reporting system. Xie, Davidson III and DaDalt (2003) suggest that board size and percentage of independent directors in the board can be used as proxies of strength of governance and board monitoring mechanism. As evidenced by Lin and Liu (2009), firms with smaller size of supervisory board and dual capacity of CEO and the board chairperson are less likely to hire high-quality auditors. External (or independent) directors are appointed to exercise the monitoring function on the operations of listed firms, and therefore, firms with higher portion of external directors are likely to hire high-quality auditors (Cheng \& Leung, 2012). Nevertheless, the revised Company Law (2005) and Securities Law (2005) explicitly provide legal responsibilities for the listed firms together with their directors and managers which and who provide fraudulent financial information to their shareholders (Note 4). Therefore, it is uncertain whether internal management structure still has the significance influence in the auditor choice.

External governance mechanisms-institutional framework and marketization. In addition to ownership structure and internal management structure, external governance mechanisms may also have influence on the auditor choice. Wang and Xin (2011) find that Big 4 auditors play a meaningful role in improving earnings quality in firms dual-listed in Hong Kong and China (i.e. A/H shares) from 1998 to 2008, maybe because the institutional framework in Hong Kong for investor protection has been well established. Besides, Wang, Wong and Xia (2008) find that central SOEs in regions, where institutions are less developed, and local SOEs are more likely to hire small local auditors from 1993 to 2003, maybe because the auditor choice decisions are derived by collusion incentives or local auditors' superior knowledge. Leung and Cheng (2013) further conclude that the firm value of Chinese listed firms registered in eastern coastal (well developed) region is higher than that of firms registered elsewhere. Therefore, external governance factors seem to have a significant influence on the auditor choice.

\subsection{Research Question}

Previous literature in developed and emerging markets (including China) supports that audit is one of corporate governance mechanisms (CGMs), but most scholars find that Big 4 auditors are more independent from audit clients and governments (e.g., DeFond, Wong \& Li, 2000; Wang, Wong \& Xia, 2008) and are more likely to issue modified (qualified) audit opinion once they detect the irregularities on the financial statements of their audit clients, and therefore they are often regarded as "high-quality" auditors. In China, previous literature evidences that certain CGMs show respective positive and negative associations with the auditor choice. Therefore, the following research question (RQ) is recited as:

$R Q$ : What is the key corporate governance factors related to the auditor choice in Chinese listed firms?

\section{Data source and Research Design}

\subsection{Data Source and Sample Selection}

This study examines the association between corporate governance mechanisms and auditor choice of Chinese listed firms after substantial reform of institutional framework in China in 2006 as mentioned in Section 1.2. Our study covers 6 years, from 2007 to 2012, and the data was obtained from the China Stock Market and Accounting Research Data Base (CSMAR) that are commonly used by scholars in the research of financial accounting and corporate governance in China (e.g., Wang, Wong \& Xia, 2008; Firth, Rui \& Wu, 2012; Leung \& Cheng, 2013). There are 11955 Chinese main-board A-share firm-year observations for these 6 years available from the CSMAR.

\subsection{Regression Model}

Section 2 describes that many scholars use Big 4 auditors as the proxy for high-audit quality. The logistic regression of this study is run to examine the association between the corporate governance mechanisms and auditor choice in Chinese listed firms as follows:

$$
\begin{aligned}
& \mathrm{BIG}_{i, t}=\beta_{0}+\beta_{1} \mathrm{TOP}_{i, t}\left(\mathrm{TOP}^{2}{ }_{i, t}\right)+\beta_{2} \mathrm{TOP} 2_{-} 5_{i, t}+\beta_{3} \operatorname{lnBOS}_{i, t}+\beta_{4} \operatorname{lnBOD}_{i, t}+\beta_{5} \mathrm{DUAL}_{-} \mathrm{CAP}_{i, t}+\beta_{6} \mathrm{EXT}_{-} \mathrm{DIR}_{i, t}+ \\
& \beta_{7} \text { UNPAID_DIR }_{i, t}+\beta_{8} \text { TOPEXE_SHARE }_{i, t}+\bar{\beta}_{9} \text { DUAL_LIST }_{i, t}+\beta_{10} \mathrm{MI}_{i, t}+\beta_{11} \operatorname{lnTA}_{i, t}+\bar{\beta}_{12} \mathrm{LEV}_{i, t}+\beta_{13} \mathrm{GROW}_{-} \overline{\mathrm{TA}}_{i, t} \\
& +\beta_{14} \text { GROW_SALES } i, t+\bar{\beta}_{15} \mathrm{TAC}_{i, t}+\beta_{16} \mathrm{TQ}_{i, t}+\beta_{17} \text { FIXED_EFFECTS }_{i, t}+\varepsilon_{i, t}
\end{aligned}
$$

Where $\varepsilon$ is the random error term of the model; $i$ is the $i$ th firm and $t$ is the year.

As mentioned in Section 2, there are two controversial issues on the concentrated ownership of the largest shareholders on the auditor choice. Leung and Cheng (2013) find that there is a non-linear association between ownership of the largest shareholders and firm valuation, and therefore, in the additional test, $\mathrm{TOP}^{2}$ is inserted 
into (1) to replace TOP1 to examine whether there is a non-linear association between ownership of the largest shareholders and firm valuation.

Table 2 contains summary descriptions of the variables used in the empirical analysis. More specifically, this study includes some variables which may be missing in some related studies: (1) the proportion of unpaid directors, UNPAID_DIR, is included because those unpaid directors are mostly appointed by the large shareholders and they may act towards the wills of those who appoint them; and (2) the potential development indicators of listed firms, GROW_TA and GROW_SALES, are included.

Table 2. Variable descriptions

\begin{tabular}{|c|c|}
\hline Dependent variables & Definition \\
\hline BIG4 & KPMG, PwC, Deloitte and Ernst \& Young \\
\hline \multicolumn{2}{|l|}{ Testing variables } \\
\hline TOP1 & Percentage of shares held by the largest shareholder \\
\hline TOP2_5 & Aggregate percentage of shares held by the second to fifth large shareholders \\
\hline $\operatorname{lnBOS}$ & Natural logarithm of the number of supervisors in the supervisory committee \\
\hline $\operatorname{lnBOD}$ & Natural logarithm of the number of directors in the board of directors \\
\hline DUAL_CAP & $\begin{array}{l}\text { Dummy variable; } 1 \text { if the chairperson of the board and CEO are the same person, } 0 \\
\text { otherwise }\end{array}$ \\
\hline EXT_DIR & Proportion of independent directors to the total directors on board \\
\hline UNPAID_DIR & Proportion of unpaid directors in the board of directors \\
\hline TOPEXE_SHARE & Aggregate percentage of shares held by the top executives (including directors) \\
\hline DUAL_LIST & $\begin{array}{l}\text { Dummy variable; } 1 \text { if the listed firm is also listed as B-shares or H-shares, } 0 \\
\text { otherwise }\end{array}$ \\
\hline MI & $\begin{array}{l}\text { Dummy variable; } 1 \text { if the listed firm is registered in the eastern coastal area (Note } \\
5), 0 \text { otherwise }\end{array}$ \\
\hline \multicolumn{2}{|l|}{ Control variables } \\
\hline $\operatorname{lnTA}$ & Natural logarithm of the total assets at year end (representing "firm size") \\
\hline LEV & Total long-term liabilities to the total assets at year end \\
\hline GROW_TA & $\frac{T A_{t}-T A_{t-1}}{T A_{t-1}}$, where TA is the total assets of listed firms at year end \\
\hline GROW_SALES & $\frac{S A L E S_{t}-S A L E S_{-1}}{S A L E S_{t-1}}$, where SALES is the total sales for the year. \\
\hline \multirow[b]{2}{*}{ TAC } & $\frac{N P-O C F}{T A}$, where NP and OCF are the profit (loss) and operating cash flows for the \\
\hline & $\begin{array}{l}\text { year respectively whereas TA is the total assets at year end (representing } \\
\text { "accounting accruals") }\end{array}$ \\
\hline TQ & $\begin{array}{l}\text { Tobin-Q value as a ratio of the market value of equity of a firm to the book value of } \\
\text { its assts }\end{array}$ \\
\hline FIXED_EFFECTS & $\begin{array}{l}\text { Dummy variables controlling the fixed effects of calendar years and industries (see } \\
\text { Table 5) }\end{array}$ \\
\hline C_SCLF & $\begin{array}{l}\text { Dummy variable; } 1 \text { if the listed firm whose ultimate shareholder is central } \\
\text { government, } 0 \text { otherwise }\end{array}$ \\
\hline L_SCLF & $\begin{array}{l}\text { Dummy variable; } 1 \text { if the listed firm whose ultimate shareholder is local } \\
\text { government }\end{array}$ \\
\hline N_SCLF & $\begin{array}{l}\text { Dummy variable; } 1 \text { if the listed firm whose ultimate shareholder is neither central } \\
\text { government nor local government }\end{array}$ \\
\hline
\end{tabular}

\section{Research Results and Interpretation}

\subsection{Descriptive Statistics}

Table 3 presents the details of the sample of this study. Our sample covers from 2007 to 2012 based on the firm's data available from the CSMAR. There are 11955 firm-year observations for these 6 years, of which 210 
observations from the financial sector (Note 6) and 758 observations with missing variables are removed. Our final sample contains 10987 firm-year observations.

Table 3. Details of the sample

\begin{tabular}{|c|c|c|}
\hline & & $\begin{array}{l}\text { Number of } \\
\text { firm-year } \\
\text { observations }\end{array}$ \\
\hline \multicolumn{2}{|c|}{ Raw sample } & 11955 \\
\hline \multirow[t]{2}{*}{ Less: } & Firms engaged in financial sector & 210 \\
\hline & Firms with missing variables & 758 \\
\hline \multicolumn{2}{|c|}{ Total available firm-year observations } & 10987 \\
\hline
\end{tabular}

Table 4 presents the descriptive statistics. The mean of BIG4 is $6.0 \%$, indicating that the engagement of Big 4 auditors in Chinese listed firms is rare. The means of TOP1 and TOP2 5 are $36.6 \%$ and $16.8 \%$ respectively, indicating that ownership of the largest shareholders in Chinese listed firms remains the same before and after the share reform and the alignment of other large shareholders is unlikely to restrict the acts of the largest shareholders in Chinese listed firms. The mean of DUAL_CAP is $21.0 \%$, indicating that most Chinese listed firms have followed the professional recommendation to assign different persons to these two roles. The mean of EXT_DIR is 36,6\%, fulfilling the requirements of independent directors in the management board of Chinese Listing Rules. The mean of UNPAID_DIR is $23.6 \%$, indicating that about one-fourth of Chinese listed firms still have the directors assigned by the large shareholders. The mean of MI is $58.0 \%$, indicating that more than half of Chinese listed firms are registered in the eastern coastal (well-developed) region.

Table 4. Descriptive statistics of the variables

\begin{tabular}{llllll}
\hline & Number & Minimum & Maximum & Mean & StdDev \\
\hline BIG4 & 10987 & 0.000 & 1.000 & 0.060 & 0.235 \\
TOP1 & 10987 & 0.022 & 0.894 & 0.366 & 0.155 \\
TOP2_5 & 10987 & 0.001 & 0.610 & 0.168 & 0.120 \\
lnBOS & 10987 & 0.000 & 2.565 & 1.294 & 0.289 \\
lnBOD & 10987 & 1.099 & 2.890 & 2.183 & 0.201 \\
DUAL_CAP & 10987 & 0.000 & 1.000 & 0.210 & 0.411 \\
EXT_DIR & 10987 & 0.091 & 0.800 & 0.366 & 0.533 \\
UNPAID_DIR & 10987 & 0.000 & 0.750 & 0.236 & 0.192 \\
TOPEXE_SHARE & 10987 & 0.000 & 0.390 & 0.089 & 0.191 \\
DUAL_LIST & 10987 & 0.000 & 1.000 & 0.070 & 0.259 \\
MI & 10987 & 0.000 & 1.000 & 0.580 & 0.493 \\
lnTA & 10987 & 15.715 & 28.405 & 21.686 & 1.277 \\
LEV & 10987 & 0.000 & 0.806 & 0.070 & 0.106 \\
GROW_TA & 10987 & -0.877 & 4719.612 & 1.466 & 61.300 \\
GROW_SALES & 10987 & -2840.523 & 10802.953 & 0.816 & 109.015 \\
TAC & 10987 & -3.217 & 21.988 & 0.002 & 0.238 \\
TQ & 10987 & 0.000 & 174.911 & 1.905 & 2.742 \\
\hline
\end{tabular}

Table 5 presents the frequencies of dummy variables by year. BIG4 remains about $6 \%$ over those 6 years. State-controlled listed firms (C_SCLF and L_SCLF) still amount to $51 \%$ in Chinese listed firms, but there is a decreasing trend, i.e. privatization of state owned enterprises. More surprisingly, DUAL_CAP and DUAL_LIST are increasing and decreasing respectively, indicating that there may a perceived detriment of the development of corporate governance in Chinese listed firms. 
Table 6 presents the distribution of ownership of the largest shareholders in Chinese listed firms. It indicates that more than $86 \%$ of the largest shareholders hold ownership over $20 \%$ in Chinese listed firms and they are at least able to exercise significant influence on them. More surprisingly, more than $20 \%$ of the largest shareholders hold ownership over $50 \%$ in those firms, i.e. they can even have a dominant influence on particular firms.

Table 7 presents correlation coefficients. The statistics show significant positive correlations between BIG4 and TOP1, TOP2_5, InBOS, InBOD, EXT_DIR, UNPAID_DIR, DUAL_LIST, MI, lnTA and LEV, but negative correlations with DUAL_CAP, TOPEX E_SHARE, TAC and TQ. The correlation coefficients between the independent variables are generally low, indicating that multicollinearity is unlikely to be a series problem in the interpretation of the results.

Table 5. Descriptive statistics of dummy variables

\begin{tabular}{|c|c|c|c|c|c|c|c|c|c|c|c|c|c|c|}
\hline & \multicolumn{2}{|c|}{2007} & \multicolumn{2}{|c|}{2008} & \multicolumn{2}{|l|}{2009} & \multicolumn{2}{|l|}{2010} & \multicolumn{2}{|l|}{2011} & \multicolumn{2}{|l|}{2012} & \multicolumn{2}{|l|}{ Total } \\
\hline & No. & $\%$ & No. & $\%$ & No. & $\%$ & No. & $\%$ & No. & $\%$ & No. & $\%$ & No. & $\%$ \\
\hline BIG4 & 95 & 6.83 & 96 & 6.57 & 96 & 6.05 & 108 & 5.61 & 123 & 5.55 & 129 & 5.36 & 647 & 5.89 \\
\hline DUAL_CAP & 224 & 16.12 & 238 & 16.29 & 284 & 17.91 & 428 & 22.22 & 568 & 25.61 & 620 & 25.77 & 2362 & 21.50 \\
\hline DUAL_LIST & 122 & 8.78 & 124 & 8.49 & 128 & 8.07 & 133 & 6.91 & 139 & 6.27 & 148 & 6.15 & 794 & 7.23 \\
\hline MI & 748 & 53.81 & 810 & 55.44 & 886 & 55.86 & 1129 & 58.62 & 1341 & 60.46 & 1474 & 61.26 & 6388 & 58.14 \\
\hline C_SCLF & 260 & 18.71 & 278 & 19.03 & 304 & 19.17 & 328 & 17.03 & 339 & 15.28 & 342 & 14.21 & 1851 & 16.85 \\
\hline L_SCLF & 611 & 43.96 & 604 & 41.34 & 613 & 38.65 & 633 & 32.87 & 633 & 28.54 & 653 & 27.14 & 3747 & 34.10 \\
\hline N_SCLF & 519 & 37.34 & 579 & 39.63 & 669 & 42.18 & 965 & 50.10 & 1246 & 56.18 & 1411 & 58.65 & 5389 & 49.05 \\
\hline \multicolumn{15}{|l|}{ Industry: } \\
\hline A & 27 & 1.95 & 28 & 1.92 & 30 & 1.89 & 37 & 1.92 & 41 & 1.84 & 45 & 1.86 & 208 & 1.90 \\
\hline B & 43 & 3.09 & 45 & 3.08 & 48 & 3.03 & 52 & 2.70 & 57 & 2.57 & 62 & 2.57 & 307 & 2.79 \\
\hline $\mathrm{C}$ & 784 & 56.40 & 836 & 57.22 & 903 & 56.94 & 1148 & 59.61 & 1357 & 61.18 & 1475 & 61.31 & 6503 & 59.19 \\
\hline $\mathrm{D}$ & 65 & 4.68 & 65 & 4.45 & 67 & 4.22 & 70 & 3.63 & 73 & 3.29 & 74 & 3.08 & 414 & 3.77 \\
\hline E & 28 & 2.01 & 29 & 1.98 & 36 & 2.27 & 39 & 2.02 & 47 & 2.12 & 52 & 2.16 & 231 & 2.10 \\
\hline $\mathrm{F}$ & 59 & 4.24 & 59 & 4.04 & 63 & 3.97 & 71 & 3.69 & 73 & 3.29 & 77 & 3.20 & 402 & 3.66 \\
\hline G & 71 & 5.11 & 78 & 5.34 & 95 & 5.99 & 137 & 7.11 & 169 & 7.62 & 198 & 8.23 & 748 & 6.81 \\
\hline $\mathrm{H}$ & 93 & 6.69 & 97 & 6.64 & 106 & 6.68 & 114 & 5.92 & 123 & 5.55 & 127 & 5.28 & 660 & 6.01 \\
\hline $\mathrm{J}$ & 107 & 7.70 & 114 & 7.80 & 123 & 7.76 & 125 & 6.49 & 125 & 5.64 & 128 & 5.32 & 722 & 6.57 \\
\hline $\mathrm{K}$ & 49 & 3.53 & 47 & 3.22 & 53 & 3.34 & 61 & 3.17 & 73 & 3.29 & 81 & 3.37 & 364 & 3.31 \\
\hline $\mathrm{L}$ & 17 & 1.22 & 17 & 1.16 & 17 & 1.07 & 24 & 1.25 & 31 & 1.40 & 36 & 1.50 & 142 & 1.29 \\
\hline M & 47 & 3.38 & 46 & 3.15 & 45 & 2.84 & 48 & 2.49 & 49 & 2.21 & 51 & 2.12 & 286 & 2.60 \\
\hline Total & 1390 & 100.00 & 1461 & 100.00 & 1586 & 6100.00 & 1926 & 100.00 & 2218 & 100.00 & 2406 & 6100.00 & 10987 & 100.00 \\
\hline
\end{tabular}

Table 6. Distribution of ownership of the largest shareholders in Chinese listed firms

\begin{tabular}{lllllllllllllll}
\hline & 2007 & \multicolumn{3}{c}{2008} & \multicolumn{3}{c}{2009} & & 2010 & & 2011 & & 2012 & \multicolumn{3}{c}{ Total } \\
\hline & No. & $\%$ & No. & $\%$ & No. & $\%$ & No. & $\%$ & No. & $\%$ & No. & $\%$ & No. & $\%$ \\
\hline $0-20 \%$ & 181 & 13.03 & 197 & 13.49 & 224 & 14.13 & 270 & 14.03 & 315 & 14.21 & 338 & 14.05 & 1525 & 13.87 \\
$20-30 \%$ & 366 & 26.33 & 361 & 24.71 & 397 & 25.03 & 485 & 25.18 & 559 & 25.20 & 620 & 25.77 & 2788 & 25.38 \\
$30-40 \%$ & 294 & 21.15 & 306 & 20.94 & 329 & 20.74 & 408 & 21.18 & 478 & 21.55 & 510 & 21.20 & 2325 & 21.16 \\
$40-50 \%$ & 264 & 18.99 & 276 & 18.89 & 285 & 17.97 & 350 & 18.17 & 398 & 17.94 & 423 & 17.58 & 1996 & 18.17 \\
Over 50\% & 285 & 20.50 & 321 & 21.97 & 351 & 22.13 & 413 & 21.44 & 468 & 21.10 & 515 & 21.40 & 2353 & 21.42 \\
Total & 1390 & 100.00 & 1461 & 100.00 & 1586 & 100.00 & 1926 & 100.00 & 2218 & 100.00 & 2406 & 100.00 & 10987 & 100.00 \\
\hline
\end{tabular}


Table 7. Correlation matrix

\begin{tabular}{|c|c|c|c|c|c|c|c|c|c|c|c|c|c|c|c|c|c|}
\hline & (1) & $(2)$ & (3) & (4) & (5) & (6) & (7) & $(8)$ & (9) & $(10)$ & (11) & (12) & (13) & (14) & (15) & (16) & (17) \\
\hline BIG 4 (1) & 1 & & & & & & & & & & & & & & & & \\
\hline TOP1 (2) & $0.140^{* * *}$ & 1 & & & & & & & & & & & & & & & \\
\hline $\mathrm{TOP}^{2}(3)$ & $0.147^{* *}$ & $0.974^{* *}$ & 1 & & & & & & & & & & & & & & \\
\hline TOP2_5 (4) & $0.066^{* *}$ & $-0.312^{* *}$ & $-0.332^{* * *}$ & 1 & & & & & & & & & & & & & \\
\hline $\operatorname{lnBOS}(5)$ & $0.110^{* *}$ & $0.047^{* *}$ & $0.052^{* *}$ & $-0.078^{* * *}$ & 1 & & & & & & & & & & & & \\
\hline $\ln B O D(6)$ & $0.123^{* * *}$ & 0.005 & 0.012 & $0.033^{* *}$ & $0.324^{* *}$ & 1 & $*$ & & & & & & & & & & \\
\hline DUAL_CAP (7) & $-0.064^{* *}$ & $-0.052^{* *}$ & $-0.055^{* *}$ & $0.125^{* *}$ & $-0.158^{* *}$ & $-0.151^{* *}$ & 1 & & & & & & & & & & \\
\hline EXT_DIR (8) & $0.051^{* *}$ & $0.056^{* *}$ & $0.064^{* *}$ & -0.010 & $-0.098^{* *}$ & $-0.369^{* *}$ & $0.078^{* *}$ & 1 & & & & & & & & & \\
\hline UNPAID_DIR (9) & $0.053^{* *}$ & $0.129^{* * *}$ & $0.122^{* *}$ & $-0.111^{* *}$ & $0.165^{* *}$ & $0.186^{* *}$ & $-0.161^{* *}$ & $-0.194^{* *}$ & 1 & & & & & & & & \\
\hline TOPEXE_SHARE (10) & $-0.093^{* * *}$ & $-0.087^{* *}$ & $-0.103^{* * *}$ & $0.416^{* *}$ & $-0.239^{* *}$ & $-0.170^{* *}$ & $0.252^{* *}$ & $0.070^{* *}$ & $-0.313^{* *}$ & 1 & & & & & & & \\
\hline DUAL_LIST (11) & $0.442^{* *}$ & $0.052^{* *}$ & $0.052^{* *}$ & $0.079^{* *}$ & $0.099^{* *}$ & $0.096^{* *}$ & $-0.045^{* * *}$ & $0.022^{*}$ & $0.050^{* * *}$ & $-0.126^{* *}$ & 1 & & & & & & \\
\hline MI (12) & $0.100^{* *}$ & $0.047^{* *}$ & $0.037^{* *}$ & $0.126^{* *}$ & $-0.133^{* *}$ & $-0.051^{* *}$ & $0.091^{* *}$ & 0.016 & $-0.022^{*}$ & $0.170^{* *}$ & $0.112^{* *}$ & 1 & & & & & \\
\hline LnTA (13) & $0.403^{* *}$ & $0.286^{* *}$ & $0.307^{* *}$ & $-0.110^{* *}$ & $0.259^{* *}$ & $0.287^{* *}$ & $-0.178^{* *}$ & $0.044^{* *}$ & $0.097^{* *}$ & $-0.256^{* *}$ & $0.287^{* *}$ & $0.027^{* *}$ & 1 & & & & \\
\hline LEV (14) & $0.125^{* *}$ & $0.095^{* *}$ & $0.105^{* *}$ & $-0.095^{* *}$ & $0.174^{* *}$ & $0.155^{* *}$ & $-0.153^{* *}$ & -0.005 & $0.101^{* *}$ & $-0.225^{* *}$ & $0.104^{* *}$ & $-0.128^{* *}$ & $0.451^{* *}$ & 1 & & & \\
\hline GROW_TA (15) & -0.005 & $0.043^{* *}$ & $0.054^{* *}$ & -0.008 & -0.004 & -0.004 & -0.009 & 0.001 & 0.003 & -0.009 & -0.004 & -0.011 & 0.008 & 0.013 & 1 & & \\
\hline GROW_SALES (16) & -0.002 & 0.005 & 0.003 & -0.006 & 0.014 & -0.012 & 0.015 & 0.013 & -0.002 & -0.003 & 0.001 & -0.012 & 0.005 & -0.008 & 0.006 & 1 & \\
\hline TAC (17) & $-0.021^{*}$ & -0.003 & -0.003 & $0.048^{* *}$ & $-0.048^{* *}$ & $-0.037^{* *}$ & $0.052^{* *}$ & $0.026^{* *}$ & $-0.024^{*}$ & $0.064^{* *}$ & 0.016 & $0.035^{* *}$ & $-0.039^{* *}$ & $-0.032^{* *}$ & 0.011 & 0.002 & 1 \\
\hline TQ & $-0.047^{* *}$ & $-0.092^{* *}$ & $-0.087^{* *}$ & $-0.032^{* *}$ & $-0.031^{* *}$ & $-0.073^{* *}$ & 0.002 & 0.010 & $0.035^{* *}$ & $-0.051^{* *}$ & -0.016 & $-0.040^{* * *}$ & $-0.243^{* *}$ & $-0.098^{* *}$ & -0.006 & 0.003 & $0.028^{* *}$ \\
\hline
\end{tabular}

Note. ${ }^{*}$ Correlation is significant at the $5 \%$ level (two-tailed) and $* *$ Correlation is significant at the $1 \%$ level (two-tailed).

\subsection{Multiple Regression Analysis}

Table 8 presents regression results on the association between corporate governance mechanisms and auditor choice. TOP1 is positive to BIG4 at the $1 \%$ significant level, indicating that with an increase in ownership of the largest shareholder, a Chinese listed firm is more likely to hire high-quality auditors; such association is consistent with Ang, Cole and Lin (2000) and Fan and Wong (2005), but inconsistent with Copley and Douthett (2002) and Lin and Liu (2009). Additional sensitive tests are performed to support this conclusion (see below). TOP2_ 5 is positive to BIG4 at the $1 \%$ significant level, indicating that other large shareholders would also prefer high-quality auditor for the protection of their interests in the listed firm as expected. EXT_DIR is positive to BIG4 at the 1\% significant level consistent with Cheng and Leung (2012), indicating that the higher portion of external directors in the board, the higher likelihood the listed firm to hire BIG4 as the external directors can relieve their fiduciary duties with the effective audit monitoring. DUAL_LIST is positive to BIG4 at the $1 \%$ significant level, and such association is expected; otherwise, the listed firm has to hire another auditor which is qualified for statutory audit (B-shares listed firm) or which is qualified for the purpose of Hong Kong Stock Exchange (H-shares listed firm). MI is positive to BIG4 at the 1\% significant level, indicating that Chinese listed firms registered in the eastern coastal region (well developed) are more likely to hire high-quality auditor.

More surprisingly, BIG4 is not significant to $\operatorname{lnBOS}$ and DUAL_CAP, which is inconsistent to Lin and Liu (2009) who found that the size of supervisory board and DUAL_CAP showed respective positive and negative associations with BIG10.Our interpretation is that since both the largest (TOP1) and other large shareholders (TOP2_5) also demand for high-quality auditors, there is no other significant resistance. Additional sensitive tests are performed to support this interpretation (see below).

$\operatorname{lnTA}$ and TQ are positive to BIG4 at the $1 \%$ significant level, indicating that the listed firms with larger size and higher perceived market value are more likely to hire high-quality auditor. LEV and TAC are negative to BIG4 at $1 \%$ and $5 \%$ significant levels respectively, indicating that firms with higher gearing and accounting accruals are unlikely to hire high-quality auditors.

Additional test is rerun as TOP 1 is replaced with TOP $1^{2}$. TOP $1^{2}$ is positive to BIG4 at the $1 \%$ significant level, indicating that such association is a U-shape. Combing the effects of TOP 1 and TOP $1^{2}$ indicates that when ownership of the largest shareholder is low, a Chinese listed firm is more likely to hire a non-Big 4 auditor because the largest shareholder can extract private benefits without the effective audit monitoring from the high-quality auditor. Once ownership of the largest shareholder reaches certain level, a Chinese listed firm would hire high-quality auditor to reduce its capital raising costs. Besides, the directions and significances of the associations between BIG4 and other variables remain unchanged. 
A sensitivity test is performed. The ultimate controlling shareholders may have an influence on the auditor choice. For example, Leung and Cheng (2013) find that the corporate governance mechanisms of central state-controlled listed firms (SCLFs) differ with those of local SCLFs from 2007 to 2009; Li and Luo (2011) also find that political connected private firms lack sufficient incentives to choose high-quality auditors because of auditor independence from 2004 to 2009; and Chan, Lin and Mo (2006) find that local (non-Big 4) auditors, who have greater economic dependence on local clients and are subject to more political influence from local governments than non-local auditors, are not willing to issue qualified audit opinion from 1996 to 2002 . Therefore, following Leung and Cheng (2013), two dummy variables, C_SCLF and L_SCLF, are added into Eq. (1). As shown in Table 6, the directions and significances of those associations remain unchanged.

Table 8. Regression results on the association of corporate governance mechanisms and auditor choice

\begin{tabular}{|c|c|c|c|c|c|c|c|}
\hline & \multicolumn{4}{|l|}{ Expectedsign } & \multicolumn{3}{|l|}{ BIG4 } \\
\hline & & & & & Sensitivity & tests & \\
\hline TOP1 & $?$ & $\begin{array}{l}0.084 \\
(0.000)\end{array}$ & $* * *$ & & $\begin{array}{l}0.084 \\
(0.000)\end{array}$ & $* * *$ & \\
\hline $\mathrm{TOP}^{2}$ & $?$ & & $\begin{array}{l}0.113 \\
(0.000)\end{array}$ & $* * *$ & & $\begin{array}{l}0.111 \\
(0.000)\end{array}$ & $* * *$ \\
\hline TOP2_5 & + & $\begin{array}{l}0.173 \\
(0.000)\end{array}$ & $\begin{array}{rl}* * * & 0.178 \\
& (0.000)\end{array}$ & $* * *$ & $\begin{array}{l}0.161 \\
(0.000)\end{array}$ & $\begin{array}{rl}* * * & 0.166 \\
& (0.000)\end{array}$ & $* * *$ \\
\hline $\operatorname{lnBOS}$ & + & $\begin{array}{l}0.001 \\
(0.973)\end{array}$ & $\begin{array}{l}-0.001 \\
(0.991)\end{array}$ & & $\begin{array}{l}0.003 \\
(0.717)\end{array}$ & $\begin{array}{l}0.003 \\
(0.718)\end{array}$ & \\
\hline $\operatorname{lnBOD}$ & + & $\begin{array}{l}0.012 \\
(0.292)\end{array}$ & $\begin{array}{l}0.012 \\
(0.304)\end{array}$ & & $\begin{array}{l}0.014 \\
(0.200)\end{array}$ & $\begin{array}{l}0.014 \\
(0.214)\end{array}$ & \\
\hline DUAL_CAP & - & $\begin{array}{l}-0.002 \\
(0.651)\end{array}$ & $\begin{array}{l}-0.002 \\
(0.634)\end{array}$ & & $\begin{array}{l}-0.003 \\
(0.587)\end{array}$ & $\begin{array}{l}-0.003 \\
(0.583)\end{array}$ & \\
\hline EXT_DIR & + & $\begin{array}{l}0.163 \\
(0.000)\end{array}$ & $\begin{array}{rl}* * * & 0.160 \\
& (0.000)\end{array}$ & $* * *$ & $\begin{array}{l}0.161 \\
(0.000)\end{array}$ & $\begin{array}{rl}* * * & 0.158 \\
& (0.000)\end{array}$ & $* * *$ \\
\hline UNPAID_DIR & - & $\begin{array}{l}0.011 \\
(0.298)\end{array}$ & $\begin{array}{l}0.011 \\
(0.289)\end{array}$ & & $\begin{array}{l}0.005 \\
(0.669)\end{array}$ & $\begin{array}{l}0.005 \\
(0.678)\end{array}$ & \\
\hline TOPEXE_SHARE & + & $\begin{array}{l}-0.001 \\
(0.924)\end{array}$ & $\begin{array}{l}-0.002 \\
(0.907)\end{array}$ & & $\begin{array}{l}-0.008 \\
(0.539)\end{array}$ & $\begin{array}{l}-0.008 \\
(0.547)\end{array}$ & \\
\hline DUAL_LIST & + & $\begin{array}{l}0.300 \\
(0.000)\end{array}$ & $\begin{array}{rl}* * * & 0.300 \\
& (0.000)\end{array}$ & $* * *$ & $\begin{array}{l}0.300 \\
(0.000)\end{array}$ & $\begin{array}{rl}* * * & 0.300 \\
& (0.000)\end{array}$ & $* * *$ \\
\hline MI & + & $\begin{array}{l}0.018 \\
(0.000)\end{array}$ & $\begin{array}{rl}* * * & 0.018 \\
& (0.000)\end{array}$ & $* * *$ & $\begin{array}{l}0.017 \\
(0.000)\end{array}$ & $\begin{array}{rl}* * * & 0.017 \\
& (0.000)\end{array}$ & $* * *$ \\
\hline $\ln \mathrm{TA}$ & + & $\begin{array}{l}0.060 \\
(0.000)\end{array}$ & $\begin{array}{rl}* * * & 0.060 \\
& (0.000)\end{array}$ & $* * *$ & $\begin{array}{l}0.060 \\
(0.000)\end{array}$ & $\begin{array}{rl}* * * & 0.060 \\
& (0.000)\end{array}$ & $* * *$ \\
\hline LEV & - & $\begin{array}{l}-0.132 \\
(0.000)\end{array}$ & $\begin{array}{r}* * *-0.131 \\
(0.000)\end{array}$ & $* * *$ & $\begin{array}{l}-0.134 \\
(0.000)\end{array}$ & 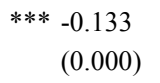 & $* * *$ \\
\hline GROW_TA & + & $\begin{array}{l}-0.001 \\
(0.488)\end{array}$ & $\begin{array}{l}-0.001 \\
(0.429)\end{array}$ & & $\begin{array}{l}-0.001 \\
(0.492)\end{array}$ & $\begin{array}{l}-0.001 \\
(0.435)\end{array}$ & \\
\hline GROW_REV & + & $\begin{array}{l}-0.001 \\
(0.554)\end{array}$ & $\begin{array}{l}-0.001 \\
(0.563)\end{array}$ & & $\begin{array}{l}-0.001 \\
(0.586)\end{array}$ & $\begin{array}{l}-0.001 \\
(0.595)\end{array}$ & \\
\hline TAC & - & $\begin{array}{l}-0.018 \\
(0.023)\end{array}$ & $\begin{array}{ll}* * & -0.018 \\
& (0.022)\end{array}$ & $* *$ & $\begin{array}{l}-0.019 \\
(0.017)\end{array}$ & $\begin{array}{ll}* * & -0.019 \\
& (0.016)\end{array}$ & $* *$ \\
\hline TQ & + & $\begin{array}{l}0.004 \\
(0.000)\end{array}$ & $\begin{array}{rl}* * * & 0.004 \\
& (0.000)\end{array}$ & $* * *$ & $\begin{array}{l}0.004 \\
(0.000)\end{array}$ & $\begin{array}{rl}* * * & 0.003 \\
& (0.000)\end{array}$ & $* * *$ \\
\hline $\begin{array}{l}\text { FIXED_EFFECTS } \\
\text { SCLF }\end{array}$ & & Included & Included & & $\begin{array}{l}\text { Included } \\
\text { Included }\end{array}$ & $\begin{array}{l}\text { Included } \\
\text { Included }\end{array}$ & \\
\hline Constant & $?$ & $\begin{array}{l}-1.433 \\
(0.000)\end{array}$ & $\begin{array}{r}* * *-1.413 \\
(0.000)\end{array}$ & $* * *$ & $\begin{array}{l}-1.436 \\
(0.000)\end{array}$ & 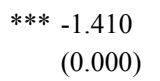 & $* * *$ \\
\hline Adj- $R^{2}$ & & 0.297 & 0.298 & & 0.300 & 0.300 & \\
\hline F-stat. & & 146.377 & 146.674 & & 139.542 & 139.794 & \\
\hline OBS & & 10987 & 10987 & & 10987 & 10987 & \\
\hline
\end{tabular}

Note. P test values are in parentheses. ${ }^{*}, *$ and $* * *$ indicate significance at the $10 \%, 5 \%$ and $1 \%$ levels, respectively. 


\subsection{Supplementary Tests}

In order to address the U-shape pattern of the association between TOP1 and BIG4, the authors conduct two supplementary tests.

As mentioned in Lin and Liu (2009), even though most Chinese listed firms have a very concentrated ownership structure in the hand of their largest shareholders, some do not (e.g. the largest shareholder of Minseng Bank holds less than 10\%). First, the authors rerun Eq. (1) by limiting ownership of the largest shareholders (1) not lower than $20 \%$, (2) not lower $30 \%$ and (3) more than $50 \%$, of the total equity shares from the sample. Table 9 presents the empirical results of this test. In the $50 \%$ cut off, TOP1 is positive to BIG4, without significance, implying that the incentive for the largest shareholder to engage the Big 4 auditors becomes weaker, because it can exercise an effective control on the listed firm when its ownership is over 50\%. Other than this, all associations are substantially the same as those in Table 8 .

Table 9. Supplementary test on the regression results on the association of corporate governance mechanisms and auditor choice $(20 \%, 30 \%$ and $50 \%$ cut off)

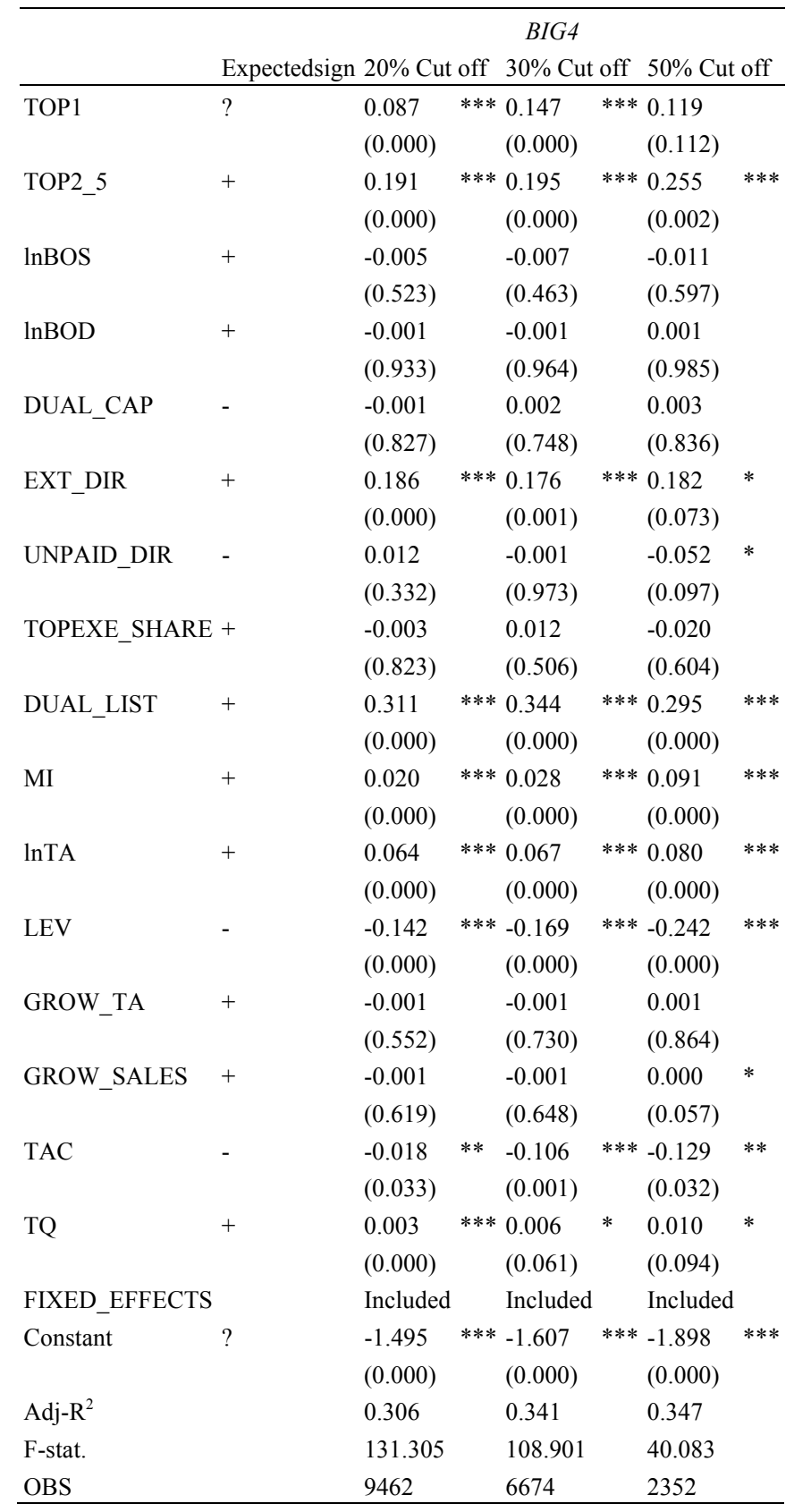

Note. P test values are in parentheses. *, ** and *** indicate significance at the $10 \%, 5 \%$ and $1 \%$ levels, respectively. 
Second, the authors set the threshold of ownership at $20 \%$ as the largest shareholders can get significant influence in Chinese listed firms. The authors rerun Eq. (1) by limiting ownership of the largest shareholders (1) lower than $10 \%$, (2) lower than $15 \%$ and (3) lower than $20 \%$, of the total equity shares from the sample. Table 10 presents the empirical results of this supplementary test. In all those ranges, TOP 1 is negative to BIG 4 at $1 \%$ and $5 \%$ significant level, implying that the incentive for the largest shareholder to engage the low-quality auditor becomes clear, because there is high deviation between cash flow right and control right of ownership of the largest shareholders and the largest shareholders do not prefer the higher audit quality for the possibility of tunneling. The associations between other corporate governance factors and BIG4 are similar to those shown in Table 8 .

Table 10. Supplementary regression on the regression results on the association of corporate governance mechanisms and auditor choice (Top1 $<20 \%$ )

\begin{tabular}{|c|c|c|c|c|c|c|c|}
\hline & & & & $B I G 4$ & & & \\
\hline & Expectedsign & TOP $1<$ & $10 \%$ & TOP $1<1$ & $15 \%$ & TOP $1<2$ & $20 \%$ \\
\hline TOP1 & $?$ & -3.265 & $* * *$ & -0.886 & $* * *$ & -0.227 & $* *$ \\
\hline & & $(0.001)$ & & $(0.000)$ & & $(0.026)$ & \\
\hline TOP2_5 & + & 0.257 & & -0.003 & & -0.011 & \\
\hline & & $(0.323)$ & & $(0.974)$ & & $(0.785)$ & \\
\hline $\operatorname{lnBOS}$ & + & 0.087 & & 0.006 & & 0.031 & $* *$ \\
\hline & & $(0.128)$ & & $(0.796)$ & & $(0.028)$ & \\
\hline $\ln B O D$ & + & 0.138 & & 0.086 & $* * *$ & 0.082 & $* * *$ \\
\hline & & $(0.111)$ & & $(0.01)$ & & $(0.000)$ & \\
\hline DUAL_CAP & - & -0.011 & & -0.017 & & -0.011 & \\
\hline & & $(0.747)$ & & $(0.219)$ & & $(0.223)$ & \\
\hline EXT_DIR & + & -0.055 & & -0.042 & & -0.087 & \\
\hline & & $(0.827)$ & & $(0.708)$ & & $(0.221)$ & \\
\hline UNPAID_DIR & - & 0.022 & & 0.022 & & 0.030 & \\
\hline & & $(0.814)$ & & $(0.521)$ & & $(0.154)$ & \\
\hline TOPEXE_SHARE & + & 0.183 & & 0.117 & $* *$ & 0.037 & \\
\hline & & $(0.237)$ & & $(0.040)$ & & $(0.224)$ & \\
\hline DUAL_LIST & + & 0.398 & $* * *$ & 0.244 & $* * *$ & 0.222 & $* * *$ \\
\hline & & $(0.000)$ & & $(0.000)$ & & $(0.000)$ & \\
\hline MI & + & -0.020 & & -0.016 & & 0.002 & \\
\hline & & $(0.568)$ & & $(0.246)$ & & $(0.816)$ & \\
\hline $\operatorname{lnTA}$ & + & 0.080 & $* * *$ & * 0.062 & $* * *$ & 0.033 & $* * *$ \\
\hline & & $(0.000)$ & & $(0.000)$ & & $(0.000)$ & \\
\hline LEV & - & 0.556 & $* *$ & 0.110 & & -0.075 & $*$ \\
\hline & & $(0.015)$ & & $(0.134)$ & & $(0.081)$ & \\
\hline GROW_TA & + & 0.200 & & 0.008 & & 0.003 & \\
\hline & & $(0.440)$ & & $(0.523)$ & & $(0.626)$ & \\
\hline GROW_SALES & + & 0.000 & & -0.001 & & -.0001 & \\
\hline & & $(0.302)$ & & $(0.664)$ & & $(0.656)$ & \\
\hline TAC & - & 0.443 & $* * *$ & ${ }^{*} 0.031$ & & -0.007 & \\
\hline & & $(0.005)$ & & $(0.492)$ & & $(0.835)$ & \\
\hline
\end{tabular}




\begin{tabular}{|c|c|c|c|c|c|}
\hline \multirow[t]{2}{*}{ TQ } & \multirow[t]{2}{*}{+} & 0.038 & $* * * 0.016$ & \multicolumn{2}{|l|}{$* * * 0.003$} \\
\hline & & $(0.001)$ & $(0.000)$ & $(0.124)$ & \\
\hline \multicolumn{2}{|c|}{ FIXED_EFFECTS } & Included & Included & Includec & \\
\hline \multirow[t]{2}{*}{ Constant } & \multirow[t]{2}{*}{$?$} & -1.986 & $* * *-1.451$ & $* * *-0.864$ & $* * *$ \\
\hline & & $(0.000)$ & $(0.000)$ & $(0.000)$ & \\
\hline Adj- $R^{2}$ & & 0.624 & 0.435 & 0.261 & \\
\hline F-stat. & & 10.796 & 16.655 & 17.846 & \\
\hline OBS & & 184 & 653 & 1525 & \\
\hline
\end{tabular}

Note. P test values are in parentheses. ${ }^{*}, *$ and $* * *$ indicate significance at the $10 \%, 5 \%$ and $1 \%$ levels, respectively.

\subsection{Summary of Regression Results}

This study finds that there is a U-shaped pattern between ownership of the largest shareholders and the engagement of high-quality auditors, and in general, other large shareholders, the higher independent board, dual-listed firms and those registered in the eastern costal (more developed) regions also prefer the engagement of high-quality auditors. Other than those, no CGMs seem to have significant influence the auditor choice.

\section{Conclusion}

Even though several scholars believe Big 4 auditors as high-quality auditors for Chinese stock market, auditing services in China are still dominated by domestic accounting firms, and Big 4 auditors only account for about 6\% from 2007 to 2012 in Chinese stock market, maybe because, on one hand, Chinese listed firms in which their largest shareholders who hold less than the threshold value (say 20\%) (i.e. greater deviation between cash flow right and control right) would not engage Big 4 auditors as they do not prefer the better audit quality and therefore, they can maximize their private benefits through tunneling or expropriation of other shareholders (internal factor), and on the other hand, Big 4 auditors would not select the listed clients which are registered in non-eastern coastal regions, higher accounting accruals, smaller firm size and higher gearing (external factors). Besides, Wang, Wong and Xie (2008) find that Chinese listed firms have a preference to hire auditors within the same regions. Further, Liu and Subramaniam (2013) illustrate large auditors tend to charge the central SOEs lower audit fees than local SOEs taking the audit risk assessment and audit effort into account. Therefore, in order to enhance the audit quality in Chinese accounting profession, the policy makers can encourage the foreign auditors (including Big 4 auditors) to collaborate and merge with the domestic accounting firms, and provide incentive to foreign auditors to set up branches in non-eastern coastal region.

\section{References}

Anderson, U., Kadous, K., \& Koonce, L. (2004). The role of incentives to manage earnings and quantification in auditor's evaluations of management-provided information. Auditing: A Journal of Practice \& Theory, 23(1), 11-27. http://dx.doi.org/10.2308/aud.2004.23.1.11

Ang, J., Cole, R., \& Lin, J. (2000). Agency costs and ownership structure. Journal of Finance, 55(1), 81-106. http://dx.doi.org/10.1111/0022-1082.00201

Ashbaugh, H., \& Warfield, T. D. (2003). Audits as a corporate governance mechanism: Evidence from the German market. Journal of International Accounting Research, 2(1), 1-21. http://dx.doi.org/10.2308/jiar.2003.2.1.1

Boone, J. P., Khurana, I. K., \& Raman, K. K. (2010). Do the Big 4 and the second-tier firms provide audits of similar quality? Journal of Accounting and Public Policy, 29(4), 320-352. http://dx.doi.org/10.1016/j.jaccpubpol.2010.06.007

Chan, K. H., Lin, K. Z., \& Mo, P. L. (2006). A political-economic analysis of auditor reporting and auditor switches. Review of Accounting Studies, 11(1), 21-48. http://dx.doi.org/10.1007/s11142-006-6394-z

Chen, J. P. C., Su, X., \& Wu, X. (2009). Forced audit firm change, continued partner-client relationship, and financial reporting quality. Auditing: A Journal of Practice \& Theory, 28(2), 227-246. http://dx.doi.org/http://dx.doi.org/10.2308/aud.2009.28.2.227 
Chen, J. P., Shrome, A., \& Su, X. (2001). How is audit quality perceived by Big 5 and local auditors in China? A Preliminary Investigation. International Journal of Auditing, 5(2), 157-175. http://dx.doi.org/10.1111/j.1099-1123.2001.00332.x

Cheng, L. T. W., \& Leung, T. Y. (2012). The effects of management demography on auditor choice and earnings quality: Evidence from China. Review of Pacific Basin Financial Markets and Policies, 15(2), 1-37. http://dx.doi.org/10.1142/S0219091511500093

Copley, P. A., \& Douthett, E. B. (2002). The association between auditor choice, ownership retained, and earnings disclosure by firms making initial public offerings. Contemporary Accounting Research, 19(1), 49-75. http://dx.doi.org/10.1506/U1Y4-CCXT-BPVE-QH58

DeFond, M. L., Wong, T. J., \& Li, S. (2000). The impact of improved auditor independence on audit market concentration in China. Journal of Accounting and Economics, 28(3), 269-305. http://dx.doi.org/10.1016/S0165-4101(00)00005-7

Fama, E., \& Jensen, M. (1983). Separation of ownership and control. Journal of Law and Economics, 26(2), 301-326.

Fan, J. P. H., \& Wong, T. J. (2005). Do external auditors perform a corporate governance role in emerging markets? Evidence from East Asia. Journal of Accounting Research, 45(1), 35-72. http://dx.doi.org/10.1111/j.1475-679x.2004.00162.x

Firth, M., Rui, O. M., \& Wu, X. (2012). How do various forms of auditor rotation affect audit quality? Evidence from China. The International Journal of Accounting, 47(1), 109-138. http://dx.doi.org/10.1016/j.intacc.2011.12.006

Francis, J. R. (2004). What do we know about audit quality? The British Accounting Review, 36(4), 345-368. http://dx.doi.org/10.1016/j.bar.2004.09.003

Gao, L., \& Kling, G. (2008). Corporate governance and tunneling in China. Pacific-Basin Finance Journal, 16, 591-605. http://dx.doi.org/10.1016/j.pacfin.2007.09.001

Guehami, O., Pittman, J. A., \& Saffar, W. (2009). Auditor choice in privatized firms: Empirical evidence on the role of state and foreign owners. Journal of Accounting and Economics, 48(2-3), 151-171. http://dx.doi.org/10.1016/j.jacceco.2009.08.003

Jensen, M., \& Meckling, W. (1976). Theory of the firm: Managerial behavior, agency costs and ownership structure. Journal of Financial Economics, 3, 305-360. http://dx.doi.org/10.1007/978-94-009-9257-3_8

La Porta, R., Lopez-De-Silanes, F., Shleifer, A., \& Vishny, R. W. (2002). Investor protection and corporate valuation. Journal of Finance, 57(3), 1147-1170.

Lee, P., Stokes, D., Taylor, S., \& Walter, T. (2003). The association between audit quality, accounting disclosures and firm-specific risk: Evidence from initial public offerings. Journal of Accounting and Public Policy, 22(5), 377-400. http://dx.doi.org/10.1016/j.jaccpubpol.2003.08.003

Leung, N. W., \& Cheng, M. (2013). Corporate governance and firm value: Evidence from Chinese state-controlled listed firms. China Journal of Accounting Research, 6(2), 89-112. http://dx.doi.org/10.1016/j.cjar.2013.03.002

Li, M., \& Luo, D. (2011). Political connections, auditor choice, and auditor independence: Evidence from private A-share listed firms in China. China Accounting and Finance Review, 13(2), 22-44.

Lin, Z. J., \& Liu, M. (2009). The impact of corporate governance on auditor choice: Evidence from China. Journal of International Accounting, Auditing and Taxation, 18(1), 44-59. http://dx.doi.org/:10.1016/j.intaccaudtax.2008.12.005

Liu, J., Wang, Y., \& Wu, L. (2011). The effect of guanxi on audit quality. Journal of Business Ethics, 103, 621-638. http://dx.doi.org/10.1007/s10551-011-0884-z

Liu, L., \& Subramaniam, N. (2013). Government ownership, audit firm size and audit pricing: Evidence from China. Journal of Accounting and Public Policy, 32(2), 161-175. http://dx.doi.org/10.1016/j.jaccpubpol.2012.11.004

Simunic, D. A., \& Wu, X. (2009). China-related research in auditing: A review and directions for future research. China Journal of Accounting Research, 2(2), 1-25. 
Wang, B., \& Xin, Q. (2011). Auditor choice and accruals pattern of cross-listed firms. China Journal of Accounting Research, 4(4), 233-251. http:// dx.doi.org/10.1016/j.cjar.2011.09.002

Wang, Q., Wong, T. J., \& Xia, L. (2008). State ownership, the institutional environment, and auditor choice: Evidence from China. Journal of Accounting and Economics, 46(1), 112-134.http://dx.doi.org/10.1016/j.jacceco.2008.04.001

Xie, B., Davidson III, W. N., \& DaDalt. (2003). Earnings management and corporate governance: The role of the board and the audit committee. Journal of Corporate Finance, 9(3), 295-316. http://dx.doi.org/10.1016/S0929-1199(02)00006-8

\section{Notes}

Note 1. This license is granted by the Ministry of Finance and China Securities Regulatory Commission in accordance with "Supplementary Provisions to the Provisions on the Administration of the Permits for Certified Public Accountants to Undertake Business Relating to Securities and Futures".

Note 2. China Securities Regulatory Committee is an institution of the State Council and it is the main regulator of the securities industry in China.

Note 3. Big 4 auditors are "KPMG, PwC, Deloitte and Ernst \& Young".

Note 4. For example, Article 203 of Company Law (2005) states that where a company makes false records or conceals important facts in such materials as its financial reports submitted to the relevant competent department according to law, the said department shall impose a fine of not less than RMB30,000 but not more than RMB300,000 on each of the persons directly in charge of the company and of the other persons directly responsible.

Note 5. Gao and Kling (2008) consider Beijing, Tianjin, Shanghai, Jiangsu, Zhejiang, Fujian and Guangdong as the developed eastern coastal region, which might exhibit better governance structures.

Note 6. Most scholars exclude those in financial sector mostly because those firms are subject to additional regulations (e.g., Wang, Wong \& Xia, 2008; Firth, Rui \& Wu, 2012; Leung \& Cheng, 2013).

\section{Appendix 1}

Summary of law and regulations concerning audit in Chinese listed firms.

Key law and regulations

1. Company Law (2005)

2. Securities Law (2005)

3. Accounting Law (1999)

4. Law on Certified Public Accountants (1993)

5. Chinese Accounting Standards (2006) and Chinese Auditing Standards (2006) (promulgated by the Ministry of Finance)

6. Supplementary Provisions to the Provisions on the Administration of the Permits for Certified Public Accountants to Undertake Business Relating to Securities and Futures

7. General Regulations on Financial Reports (promulgated by the CSRC)

Technical competence

1. The signer(s) (i.e. certified public accountant or CPA) in the audit report of Chinese enterprises should hold the membership of Chinese Institute of Certified Public Accountants, and follow the Chinese Auditing Standards (2006) which cover almost all items of international auditing criteria, including auditing works and professional responsibilities.

2. Those accounting firms which must hold "The Securities and Futures Related Business License" are eligible to conduct external audits of Chinese listed firms in accordance with Supplementary Provisions to the Provisions on the Administration of the Permits for Certified Public Accountants to Undertake Business Relating to Securities and Futures.

Independence 
1. The signers and any audit staff who conduct the auditing services are not entitled to trade the stocks of their audit clients within their underwriting periods and for six months after they expire (Article 45 of Securities Law).

2. CPAs are required to be independent in form and substance (Article 22 of Law of Certified Public Accountants and The Basic Standards of Professional Ethics for Chinese Certified Public Accountants).

3. Any issues concerning the appointment, dismissal or discontinuing appointment of external auditors shall be approved in the shareholders' meetings (Relevant Questions Concerning the Hiring and Changing of Auditors by Listed Companies, promulgated by CSRC). An audit committee is responsible for proposals on the appointment or changes to the appointment of external auditors (Chapter Six of the Code of Corporate Governance of Listed Companies).

4. A CPA should not provide auditing services to a particular listed company for five consecutive years (The Provision on Regular Rotation of Certified Public Accountants that Sign the Audits of Securities and Future (2003)).

\section{Legal responsibilities}

1. An entity shall prepare its financial statements after the end of each financial year and they shall be audited by an accounting firm (Article 165 of Company Law).

2. Civil responsibilities. If any false records, misleading statements or major omissions in the documents produced (i.e. including the prospectus and financial statements) incur any loss to any other person, an accounting firm shall bear joint liability together with the relevant issuer and listed companies, unless the accounting firm is able to provide it is not at fault (Article 173 of Securities Law). An accounting firm may also be given a warning and imposed a fine by CSRC.

3. Criminal responsibilities. A person of an intermediary body (including an external auditor) performing such functions as asset evaluation or examination, certificate examination, accounting, auditing, legal services, who provide intentionally false documentary evidence, shall be sentenced to fixed-term imprisonment, and fined concurrently if the issue is series (Article 229 of Criminal Law).

\section{Appendix 2}

Some examples of audit negligence in Chinese listed firms.

The following case study illustrates the misconducts of two non-Big 4 accounting firms on the audit of Chinese listed firms.

Case 1 North Industrial (Group) Company Limited (Stock code: S*ST600705) (the Company) and Reanda CPA Limited

China Securities Regulatory Commission (CSRC) announced the punishment decision (11/2009) on Reanda in 2009 which describes the case as:

In conducting the audit of the Company from 2002 to 2005, the audit staff of Reanda failed to verify the existence of all fixed assets, and find the accounting frauds in the fixed assets of the Company for those years.

CSRC set an administrative punishment on the accounting firm (Reanda) for penalty of RMB1.1 million and both the signers of the audit reports in those years for penalty of RMB50,000.

Case 2: Beihai Yinhe Hi-Tech Industrial Company Limited (Stock code: 000806) (the Company) and Hua Yin CPA Company Limited

CSRC announced the punishment decision (20/2011) on Hua Yin in 2011 which describes the case as:

In conducting the audit of the Company in 2004, Hua Yin was found not to request the Company to restate the accounting figures, or it did not issue qualified opinion, on the incident that the Company overstated the revenue in 2002 and 2003 which had previously been investigated by the Ministry of Finance. Besides, Hua Yin failed to detect other accounting frauds in 2004 and did not follow the proper procedures on the non-replied debtors' confirmation.

CSRC set an administrative punishment on the accounting firm (Hua Yin) for penalty of RMB400,000 and both the signers of the audit reports in those years for penalty of RMB100,000.

(Note: All punishment decisions (in Chinese) by CSRC are available from its website, www.csrc.gov.cn) 


\section{Copyrights}

Copyright for this article is retained by the author(s), with first publication rights granted to the journal.

This is an open-access article distributed under the terms and conditions of the Creative Commons Attribution license (http://creativecommons.org/licenses/by/3.0/). 